\title{
ŠPANĚLSKÝ PŘÍRODOVĚDEC A TEOLOG JUAN T. GONZÁLES DE ARINTERO, O.P. (1860-1928) A EVOLUČNÍ VZNIK - STVOŘENÍ ČLOVĚKA
}

C T I R A D V. P O S PÍ Š I L

\section{ABSTRACT \\ Spanish Natural Scientist and Theologian Juan T. Gonzáles de Arintero O.P. (1860-1928) and the Evolutionary Origin - Creation of a Man}

This study represents the life and work of the Spanish Catholic natural scientist and theologian Juan T. González de Arintero o.p. (1860-1928), who is very little known in the Czech environment. The focus of the study is the analysis of the La Evolución y la Filosofia Christiana 1. Introdución General published in 1898. Arintero walks in the footsteps of Zeferino Gonzalez, perceives Mivart's thesis as acceptable, but modifies it as Z. Gonzáles. Arinter's own contribution lies in the distinction of a so-called ontological species (biological class) and a biological species. Spontaneous evolution occurs within biological class. Once a new class arises, a direct Creator intervention is required. Human represents not only a new species or class, but even a independent kingdom. The human body is prepared by the evolution of higher primates (haplorhini). But the completion of humankind requires a direct Divine intervention which is linked to the creation of a rational soul united with this body. On the basis of our analysis, we corrected the erroneous claim which is presented in a very renowned foreign publication, according to this author Arintero rejected the evolutionary origin of the human body. Arintero expressly claims that the first human is a descendant of animal ancestors. However on the level of interpretation Arintero perceives this process as a specific God's intervention, while he respects all verified data of the Paleoanthropology and Developmental Biology. Thus, Juan Gonáles de Arintero is one of the most important pioneers of the Catholic reception of the evolutionary origin - creation of man.

\section{Key words}

Evolution; Origin of humans; Darwinism; Theology of creation; History of theology; Exegesis; Old Testament; Book of Genesis

DOI: $10.14712 / 23363398.2018 .54$ 


\section{Predkládaná studie úzce navazuje na předchozí, věnovanou} jinému španělskému dominikánovi a kardinálovi, jenž v roce 1891 ve svém díle La Biblia y la Ciencia odvážně, průkopnicky akceptoval podstatu Mivartovy teze, kterou modifikoval v tom smyslu, že předhumánní, ještě animální tělo se stalo lidským až v momentě, kdy ho Stvořitel sjednotil s racionální duší. ${ }^{1}$ Takto pojatý práh humanizace činí zadost nejenom př́mému stvoření racionální duše Bohem, ale rovněž přímému stvoření lidského těla, přičemž jeho organický základ Hospodin připravil cestou evoluce $\mathrm{z}$ biologických předků lidstva. Na jevové rovině platí to, co objevuje paleoantropologie, nicméně interpretace vlastního stvoření člověka podtrhuje specifickou Boží aktivitu, takže teologie může bez větších problémů akceptovat evoluci i na antropologické rovině.

Dále je třeba upozornit, že pasáž věnovaná problematice ostrých sporů o darwinismus ve Španělsku v letech 1860-1910, která je součástí předchozí studie, utváří pozadí i tohoto př́spěvku. ${ }^{2}$

Jak již bylo vícekrát předznamenáno $\mathrm{v}$ poměrně dlouhé sérii pilotních studií, v nichž se zabýváme anglosaskými, německými, rakouskými, italskými, francouzskými, belgickými a nyní španělskými průkopníky katolické recepce evolučního vzniku - stvoření člověka, i tento příspěvek je součástí poměrně rozsáhlého badatelského záměru, jehož cílem je pokud možno zmapovat právě nastíněný proces na rovině světové katolické teologie v letech 1871-1910 (1920).

Nikoho by tudíž nemělo překvapit, když i nyní budeme postupovat obdobně jako v předchozích případech, a proto nejprve stručně představíme životní osudy a dílo př́slušného autora a ve druhé kapitole se pak budeme zabývat jeho myšlenkovým odkazem stran předmětu našeho zájmu.

1 Srov. Cardenal Gonzáles. La Biblia y la Ciencia 1-2. Madrid: Imprenta de A. Pérez Dubrull 1891.

2 Vzhledem k tomu, že studie o Zeferinu Gonzálesovi v době vzniku tohoto příspěvku ještě nebyla editována v periodiku KTF UK, nebylo možno na ni odkazovat. 


\section{1. Životní cesta a dílo teologa přírodovědce, teologa a mystika Juana T. Gonzálese de Arintero o.p. ${ }^{3}$}

Na rozdíl do naprosté většiny předešlých studií zmíněného badatelského záměru můžeme nyní konstatovat, že v češtině existuje ze španělštiny přeložený článek věnovaný tomuto dominikánskému mysliteli z Pyrenejského poloostrova, kde jsou uvedeny základní životopisné údaje. ${ }^{4}$ Př́spěvek však nevypovídá zhola nic o tématu evoluce, které hraje v Arinterově díle opravdu výraznou roli. ${ }^{5}$

Otec Juan Gonzáles se narodil na svátek Jana Křtitele dne 24. června 1860 v Langueros, což je městečko v regionu León. ${ }^{6}$ Již jako šestiletý byl biřmován, což se dá mimo jiné vysvětlovat také neklidnou dobou, protože o dva roky později vzplála revoluce, která deponovala z trůnu korunovaného panovníka. ${ }^{7}$ Jako patnáctiletý vstoupil dne 14. července 1875 v konventu v Corias do postulátu řádu dominikánů. O dva měsíce později začal spolu s dalšími čtyřmi novými spolubratry noviciát. Rok nato složil 24. září 1876 první sliby, doživotní profesi složil dne 20. září $1879 .^{8}$

V srpnu 1881 byl vyslán do Salamanky, kde se věnoval studiu přírodních věd. V srpnu 1883 byl v katedrále téhož města vysvěcen na presbytera. Po dalších třech letech, tedy v roce 1886, dokončil svá studia na fyzikálně-chemické fakultě př́íslušné univerzity. ${ }^{9}$ Následovalo šest let působení v konventu ve Vergaře (1886-1892), kde přednášel mate-

3 V současných pracích o této osobnosti se v jejím jménu neobjevuje slůvko „de“ ani „T“. (španělsky Tomás?), nicméně v dílech zmíněného autora na titulních stránkách shledáváme oba právě uvedené prvky, a proto jsme se rozhodli zde i na několika jiných místech na tuto verzi jeho jména upozornit.

4 Srov. Armnado Bandera O.P. Tajemství církve v mystické teologii P. Arintera. Salve 10 (2000), č. 3, s. 22-30. Psaní zkratky „O.P.“ případně „o.p.“ kolísá. V titulech zachováváme ortografii dle předlohy. V našem vlastním textu se přikláníme k verzi „o.p.“, s níž se sekáváme ve španělských textech.

5 Srov. např. Ricardo Alba Sánchez. La Evolución de las Species Según Juan Gonzáles Arintero. Extrácto de la Tesis Doctorál. Pamplona: Universidad de Navarra, Facultad Eclesiástica de la Filosofía 2006.

6 Srov. P. Arturo Alonso Lobo O.P. Padre Arintero. Un domenicano all'inizio dell'opera dell'Amore Misericordioso. Roma: Edizioni di San Sisto Vecchio 2016, s. 17. Originál: El P. Arintero, precursor cleridente del Vaticano II. Salamanca: San Esteban 1970. Patrně nejrozsáhlejší Arinterův životopis je z pera dominikána, který byl jeho příbuzným: srov. Adriano Suárez O.P. Vida del M.R.P. fr. Juan G. Arintero 1-2. Cádiz 1936, 1. XVII-336 stran, 2. - 416 stran.

Srov. P. Arturo Alonso Lobo O.P. Padre Arintero, s. 18.

8 Srov. tamtéž, s. 23-29.

9 Srov. tamtéž, s. 33-37. 
matiku a př́rodní vědy. Zabýval se mineralogickým výzkumem okolí, mapoval místní faunu a flóru. ${ }^{10}$ Když měl složit přísahu, že bude vždy hájit solidní tomistickou nauku, na základě výhrady svědomí požádal o dispens, nebot' ve spisech sv. Tomáše a středověkých autorů nacházel mnohé, co nebylo v souladu s jeho př́rodovědeckými vědomostmi. Jeho žádosti bylo vyhověno. ${ }^{11}$

V letech 1892-1898 působil opět v konventu v Corias, kde zase vyučoval př́rodní vědy a matematiku. $V$ tomto období se vrátil ke studiu evolučního paradigmatu. Zpočátku byl antitransformista, prožil však něco jako intelektuální konverzi, a stal se příznivcem evolučního vysvětlení druhové rozličnosti. Je nanejvýš pravděpodobné, že rozhodující roli v této proměně smýšlení sehrálo již zmíněné dílo kardinála Zeferina Gonzálese z roku 1891. Následně pojal záměr vytvořit osmisvazkové dílo s titulem La Evolución y la Filosofia Cristiana. ${ }^{12}$ Tiskem vyšel jenom první svazek La Evolución y la Mutabilidad de las Especies Orgánicas. Ostatní svazky se zachovaly v rukopisu. ${ }^{13}$

Jestliže prozatím se Juan Gonzáles de Arintero věnoval přednostně přírodním vědám, pak v době svého druhého pobytu v Salamance (1898-1900) dostal za úkol zaměřit svou pozornost směrem k obhajobě racionality víry, tedy $\mathrm{k}$ apologetice, kterou také přednášel. ${ }^{14} \mathrm{Z}$ našeho hlediska nejpozoruhodnějším spisem z toho období je monografie $E l$ Hexameron y la Ciencia moderna. ${ }^{15}$

Na počátku 20. století, tedy v době svého dalšího působení v Salamance (1903-1909), opustil oblast přírodních věd a začal se věnovat spiritualitě, konkrétně mystice. ${ }^{16}$ I když tato oblast není předmětem našeho zájmu, sluší se připomenout spis, který bývá hodnocen jako autorovo stěžejní dílo La Evolución Mistica (1905). V témže období se věnoval ekleziologii a vytvořil čtyřsvazkovou práci Desenvolvimiento y vitalidad de la Iglesia (Rozvoj a životnost církve). ${ }^{17} \mathrm{~V}$ roce 1909 vzniklo

10 Srov. P. Arturo Alonso Lobo O.P, Padre Arientero, s. 39.

11 Srov. tamtéž, s. 41.

12 Srov. Juan T. Gonzáles de Arintero O.P. La Evolución y la Filosofía Christiana 1. Introdución General. La Evolución y la Mutabilitad de las Especies Orgánicas. Madrid: Libreria de Gregoria Amo 1898. „Introdución“ 191 stran; „La Evolución“ 548 stran.

13 Srov. P. Arturo Alonso Lobo O.P. Padre Arintero, s. 50-51.

14 Srov. tamtéž, s. 59.

15 Srov. P. fr. Juan Gonzáles de Arintero. El Hexameron y la Ciencia moderna. Valladolid: Libreria de José Manuel de la Cuest: 1901, 308 stran.

16 Srov. P. Arturo Alonso Lobo O.P. Padre Arintero, s. 67.

17 I - Salamanca 1911, 448 stran; II - Salamanca 1911, 451 stran; III - Salamanca 1908, 714 stran; IV - Salamanca 1908, 442 stran. 
ústřední řádové studium v Římě Angelicum, kde Juan Gonzáles rok přednášel právě ekleziologii. Pro jeho další životní osudy bylo velmi důležité, že se v tomto období úžeji spřátelil s jiným věhlasným dominikánem, otcem Garrigou-Lagrangem. ${ }^{18}$

V roce 1911 si prošel svízelným obdobím, protože byl napadán za své přilnutí k evoluci. Ostře proti němu v této věci vystupoval jiný dominikán, profesor ze švýcarského Fribourgu Norberto de Prado. Pravověrnost Arinterovy ekleziologie zpochybňoval jeho bývalý vlastní žák, dominikán Emilio Colunga. Profesor z římské Gregoriany, jezuita Lino Murillo našeho autora obvinil z modernismu, pročež začalo vyšetřování ze strany Kongregace Indexu i ze strany Svatého oficia. Výraznou roli v obhajobě Juana Gonzálese de Arintera sehrál již zmíněný Garrigou-Lagrange, díky němuž vyšetřování skončilo konstatováním pravověrnosti. ${ }^{19}$

Od roku 1918 se mohl věnovat svým vlastním zájmům, nebot' byl zproštěn povinnosti přednášet. Pracoval tedy na poli duchovního vedení. ${ }^{20} \mathrm{~V}$ roce 1921 založil teologicky a spirituálně zaměřené periodikum La Vida Sobrenatural. ${ }^{21}$ Stál u počátku díla Milosrdné lásky..$^{22}$ Tento svět opustil dne 20. února $1928 .^{23}$

V roce 1951 byl zahájen s Božím služebníkem Juanem Gonzálesem de Arintero beatifikační proces. ${ }^{24}$ Jestliže mezi průkopníky katolické recepce evolučního vzniku - stvoření člověka nacházíme dokonce kardinála Zeferina Gonzálese a také minimálně dva biskupy, pak mezi ně patří také vážný adept blahořečení. ${ }^{25}$

\section{2. Řešení problému evoluce a zejména evolučního vzniku - stvoření člověka v díle Juana T. Gonzálese de Arintero}

Víme již, že náš autor kolem poloviny devadesátých let předminulého století zásadně proměnil svůj postoj k transformistické teorii vzniku

\footnotetext{
Srov. tamtéž, s. 77.

Srov. tamtéž, s. 84-88.

Srov. tamtéž, s. 101-103.

Srov. tamtéž, s. 134.

Srov. tamtéž, s. $153 \mathrm{nn}$.

Srov. tamtéž, s. 181.

Srov. tamtéž, s. 192.

Podle našich zkušeností odhadujeme, že délka trvání procesu pravděpodobně souvisí s tím, že při beatifikačních kauzách tohoto typu se vyžaduje prokazatelné znamení shůry, tedy zázrak.
} 
živočišných druhů, což se projevuje zejména $\mathrm{v}$ jeho rozsáhlém spisu z roku 1898, který měl být prvním svazkem zamýšlené osmisvazkové série. ${ }^{26} \mathrm{Na}$ toto dílo se pochopitelně zaměříme podrobněji v prvním pododdílu této druhé části předkládané studie. Ve druhém pododdílu poněkud zběžněji nahlédneme do jeho dalších spisů, a to i těch ještě nevydaných, v nichž se nacházejí zmínky o evolučním vzniku - stvoření člověka.

\section{1 Transformistický způsob stvoŕení druhủ a človéka v díle Juana T. Gonzálese de Arintero O.P. La Evolución y la Filosofía Christiana 1. Introdución General.}

\section{La Evolución y la Mutabilitad de las Especies Orgánicas (EF1)}

Již na první pohled je patrné, že daný svazek obsahuje vlastně dvě monografie, z nichž první nese titul Introdución General a má být úvodem k celému zamýšlenému osmisvazkovému dílu. Prolistujeme-li první díl, který nese název La Evolución y la Mutabilidad de las Especises Orgánicas, je evidentní, že v něm jednoznačně převládají dobová přírodovědecká témata, která jsou jistě zajímavá z hlediska dějin př́rodních věd, nikoliv ale tolik pro toho, kdo zkoumá problematiku recepce transformisticky či evolučně pojímaného vzniku - stvoření člověka ze strany katolické teologie a filosofie. $Z$ uvedeného důvodu proto budeme věnovat svou pozornost první části, tedy obecnému úvodu do celé rozsáhlé práce.

Ještě předtím je třeba pohlédnout na samotný počátek knihy, kde se nachází celá řada dokumentů, vypovídajících o vzniku díla. Na titulní straně se autor představuje jako nositel titulu licenciát $\mathrm{v}$ př́rodních vědách a profesor apologetiky v konventu San Esteban. Spis je věnován biskupovi Vigilovi o.p. z Ovieda, který byl rovněž nakloněn koncepci tak zvaného umírněného nebo limitovaného transformismu. ${ }^{27}$ Následuje konstatování bezbludnosti díla ze dne 12. února 1898 ze strany pomocného biskupa z Ovieda, doktora Manuela Suáreze Garcii. ${ }^{28} \mathrm{Na}$ další straně je uveřejněno nihil obstat od řádových autorit, konkrétně od dvou dominikánských cenzorů a provinciála Fr. Estebena Sacresta

\footnotetext{
26 Srov. Juan T. Gonzáles de Arintero. O.P. La Evolución y la Filosofía Christiana 1. Introdución General. La Eevolución y la Mutabilitad de las Especies Orgánicas. Madrid: Libreria de Gregoria Amo 1898.

27 Srov. EF1, s. III. Např́klad na straně 104 je uváděn mezi apologety, kteří byli naklonění recepci umírněného transformismu ze strany katolického myšlení.

28 Srov. EF1, s. IV.
} 
z února 1898..$^{29}$ Pozoruhodný je pochvalný a knihu doporučující dopis od kardinála Casjacarese, arcibiskupa z Valladolidu. ${ }^{30}$ Dále je připojen pochvalný dopis exprezidenta pravděpodobně tomistického „Kongresu“ Alexandra Pidala y Mon ze dne 7 . listopadu $1898 .^{31}$ Předkládané dílo tedy mělo nejen všechny náležitosti, podle nichž mohl zájemce konstatovat jeho pravověrnost, ale nadto řadu doporučení. Pro nás je důležité, že Arinterova odvážná práce nacházela v rámci místní církve, řádu i odborných tomistických autorit plné schválení, což opět vypovídá o poměru zúčastněných k problematice recepce umírněného transformismu ze strany katolického myšlení v posledním desetiletí 19. století ve Španělsku.

Nyní se zaměříme na celkový úvod k zamýšlené osmisvazkové práci o možnosti recipovat evoluci ze strany katolické filosofie. Celá tato partie je rozčleněna do jedenácti paragrafů a závěru. V prvním se hovoří o aktuálním stavu př́rodovědeckého bádání. ${ }^{32}$

Ve druhém již autor podrobuje kritice některé hermeneuticky neospravedlnitelné zneužívání nových objevů a hypotéz. ${ }^{33}$ Již zde se jasně profiluje to, co je obsaženo v titulu celého záměru, totiž snaha přemostit zdánlivě nepřekročitelnou propast mezi př́rodními vědami konce 19. století na jedné straně a katolickou filosofií i teologií na straně druhé. Náš autor jasně podtrhuje, že není možno pohrdat skutečně prověřenými přínosy přírodních věd. ${ }^{34} \mathrm{Na}$ jedné z dalších stránek odkazuje na nám již z dřivějších studií známého amerického zastánce evolučního způsobu stvoření lidského těla Zahma, ${ }^{35}$ který tvrdí, že s archeology,

29 Srov. EF1, s. V.

30 Srov. EF1, s. VII-VIII.

31 Srov. EF1, s. IX-X.

32 Srov. „\$ I. Estado actual de las ciencias naturales. Sus progresos en este siglo: sus enigmas: sus tendencias."EF1, s. 1-17. Tituly jednotlivých paragrafů nepřekládáme, protože jsou vzdělanému českému čtenáři poměrně srozumitelné i v původním znění.

33 Srov. „\$ II. Las tendencias pseudo-científicas y el criterio intransigente. - Alarmas injustificadas. - Las ciencias i $\mathrm{n}$ formes y las formadas. - El criterio verdadero. Carácter de la controversia actual. - El amor á la ciencia. - Respuesta á las acusaciones." EF1, s. 18-33.

34 Srov. tamtéž, s. 23.

35 V celém spisu se vícekrát zmiňuje a cituje italský překlad původně anglicky psané monografie Evoluzione e dogma. Galea 1896. Srov. John Augustine Zahm. Evolution and Dogma. Chicago: McBride 1896, např. s. 355. Autor (1851-1921) studoval a působil na univerzitě Notre Dame ve státě Indiana. Věnoval se přednostně přírodním vědám. Papež Lev XIII. mu v roce 1895 udělil čestný doktorát z filosofie. Právě připomenutá monografie, $v$ níž je hájena Mivartova teze o vzniku lidského těla cestou evoluce a o skokovém vybavení tohoto těla racionální duší ze strany Stvořitele, měla velkou odezvu a bohužel se stala také příčinou vyšetřování ze strany vatikánských 
geology a př́rodovědci obecně je třeba vést debatu na jejich vlastním terénu, tedy nikoliv pouze na základě apriorních metafyzických pravd a soudů, nýbrž na poli empirie. ${ }^{36}$

Ve třetím paragrafu se vyjasňují metodologické principy práce apologety, který musí respektovat údaje zjevení, ctít církevní nauku i církevní otce. Arintero zároveň zdůrazňuje, že důsledně vychází z inspirací obsažených zejména v dílech sv. Augustina a sv. Tomáše Akvinského. Pokud apologeta postupuje podle právě nastíněných principů, otvírá se před ním prostor pro vlastní svobodný a zároveň odpovědný myšlenkový výkon. ${ }^{37}$

Čtvrtý paragraf ${ }^{38}$ je věnován poměru mezi př́rodními vědami, v nichž panuje empirie, a filosofií, která má metafyzickou povahu. Autor poukazuje na to, že je velkou chybou na jedné straně ignorovat filosofii, jak jsme toho svědky u řady př́rodovědců, ale stejným osudným omylem je, když filosof nebo teolog opomíjí přínosy přírodních věd. ${ }^{39}$ Jednou z hlavních příčin dobového agnosticismu je podle Arintera to, že doboví učenci vykazují ve svých spisech vpravdě zoufalou neznalost kvalitní teologie. ${ }^{40}$ Bohužel opomíjení filosofie i neznalost kvalitní teologie, která bývá zaměňována za to, co lze bez nadsázky definovat jako její mediální karikaturu, bolestně pocitujeme dnes možná ještě více než před sto dvaceti lety.

V pátém ${ }^{41}$ a šestém ${ }^{42}$ paragrafu vyjasňuje náš autor jednak stav otázky v rámci dobové katolické apologetiky i svůj postoj k evolucionismu,

úřadů. Zahm byl nucen stáhnout knihu z prodeje, ale vyhnul se formálnímu aktu odvolání zastávaných názorů, což ale oficiální vatikánské orgány prezentovaly jako akt podvolení se církevní autoritě, tedy odvolání.

41.

41 „\$ V. El evolucionismo y la apologética. - Prestigio de la evolución. - Los apologistas tímidos y los prudentes: aplausos y odios de los incrédulos. - Los abusos y su valor. El proceder más acertado. - Presunciones favorables: prevenciones." EF1. s. 69-86.

42

„S VI. Nuestro cambio. - El apasionamiento y la calma. - Polvareda levantada por Darwin. - Nuestras prevenciones. - Grandeza de Dios á través de la evolución: la especie metafísica y la orgánica. - Ventajas de un sistema harmonizador. - Obstáculos y temores. - Las tres fases de los grandes descubrimientos: lecciones de lo pasado. - Oportunidad de la defensa: estímulos y contrariedades: el justo medio.“ EF1, s. $87-107$. 
který lze definovat jako otevřený a zároveň umírněný vzhledem k různým dobovým hypotézám. Klíčové jsou podle našeho autora dvě věci. V první řadě je nutno velmi dobře rozlišovat transformismus jako vědeckou teorii a jako ideologický nástroj v rukou ateistických sektářù. ${ }^{43}$ Druhým prostředkem, jak překonat zdánlivý rozpor mezi transformismem a katolickým myšlením, je rozlišování biologického a metafyzického druhu. ${ }^{44}$ Zatímco první pojetí druhu je neměnné, druh v zoologii a botanice je vymezován jen na základě případkových záležitostí, které jsou proměnlivé, a proto druh v oboru př́rodovědy je nevyhnutelně v průběhu dlouhé doby svého trvání také variabilní. Uvedené rozlišení, které je v Arinterově koncepci evoluce klíčové, se plněji vyjasňuje až v předposledním paragrafu, kde autor předkládá své vlastní přínosy, a proto tuto věc prozatím necháme otevřenou. Zajímavé je, že španělský dominikán cituje v pozitivním smyslu Zahma a Leroye, mezi průkopníky tomistické recepce umírněného evolucionismu je zmiňován i dobře známý francouzský dominikánský myslitel A. Gardeil.45 Jsme rovněž obeznámeni s řadou jmen významných dobových apologetů, kteří se stavěli pozitivně k možnosti akceptování umírněného transformismu určitě na rovině fauny a flóry, což zpravidla neplatilo o rovině

43 Srov. tamtéž, s. 91.

44 „Las species metafísicas se fundan en la naturaleza íntima de las cosas, y, por lo tanto, son tan inmutables como esas naturalezas ó esencias; pero las especies en Zoología y en Botánica fúndanse en un conjunto de caracteres orgánicos, todos puramente accidentales, $y$, por lo tanto, son tan variables como los accidentes de las cosas, los cuales nunca permanecen en un mismo sér.“ - „Metafyzické druhy se zakládají na vnitřní přirozenosti věcí, a proto jsou natolik neměnné jako jejich přirozenosti nebo esence, avšak druh v zoologii a v botanice se zakládá na souhrnu organických charakteristik, které mají čistě případkovou povahu, a proto jsou natolik variabilní jako případky věcí, které nikdy nezůstávají týmiž.“ Tamtéž, s. 95.

45 Srov. tamtéž, s. 98, 100-101.

„A esto contribuyó no poco nuestro esclarecido hermano, P. Leroy, con las dos obritas que publicó en favor de la evolución; también ha contribuido á ello otro ilustre dominico, el P. Gardeil, con la interesante serie de artículos que ha venido publicando en la Revue Thiomiste con el título: El Evolucionismo y los principios de Santo Tomás.“„K tomu [k pozitivnějšímu hodnocení transformismu ze strany katolických apologetů] nemálo přispěl náš skvělý spolubratr pater Leroy svými dvěma knížkami, v nichž se zastal evoluce. Podobně k tomu přispěl vynikající dominikán pater Gardeil prostřednictvím zajímavé série článků, které jsou právě publikovány v Revue Thomiste s titulem Evolucionismus a principy svatého Tomáše.“ Tamtéž, s. 104.

Tento údaj je velmi cenný, protože se zde potvrzuje naše tvrzení ze studie věnované otci Leroyemu, podle něhož vystoupení tohoto průkopníka katolické recepce evolučního způsobu stvoření člověka z roku 1891 zároveň vyjadřovalo mínění většího počtu význačných francouzských dominikánů oné doby. Studie v době vzniku tohoto článku ještě nebyla uveřejněna, a proto na ni nemůžeme odkazovat. 
vzniku lidstva ${ }^{46}$ Asi nás nepřekvapí, že náš autor považuje Laplaceovu teorii a př́nosy dobové geologie za prokázané vědecké pravdy, a proto hovoří o evolučním vzniku kosmu a naší planety. ${ }^{47}$ Zároveň jako teolog podtrhuje, že všechno stvořené je dílem nekonečně mocného a moudrého Boha. ${ }^{48}$

V sedmém, ${ }^{49}$ osmém $^{50}$ a devátém paragrafu ${ }^{51}$ Arintero pojednává o různých aspektech dobové debaty o transformismu.

Z hlediska našeho nejvlastnějšího zájmu je pro nás ovšem mnohem zajímavější desátý paragraf, v němž se pojednává o průkopnících recepce transformismu z řad katolických myslitelů..$^{52}$ Na prvním místě je zmiňován vynikající přírodovědec a teolog Mivart. ${ }^{53}$ Poznamenává se, že Mivartova teze nebyla nikdy oficiálně odsouzena církevními autoritami a že Pius IX. mu navzdory kritikám ze strany odpůrců recepce transformismu udělil čestný doktorát z filosofie. ${ }^{54}$ Dále je uváděn

46 „Duilhé, Arduín, Nadaillac, J. d’Estienne, Farges, los PP. Bellinck, Carbonelle, Delsaux, Pesch, Monsabré etc., y en España el P. Zeferino, el P. Vigil y el Sr. Fajarnés." Srov. EF1, s. 104.

47 Srov. tamtéž, s. 112.

48 „Todas las cosas son obra de una Causa Primera, transcendental, infinitamente poderosa é infinitamente sabia, de un Ser por esencia, de un Dios personal, eterno, omnipotente, omnisciente é infinito.“ - „Všechny věci jsou dílem První Příčiny, která je transcendentní, nekonečně mocná a nekonečně moudrá, která je Bytím svou vlastní esencí, která je osobním, věčným, všemohoucím, vševědoucím a nekonečným Bohem.“ Tamtéž, s. 112-113. Autor ještě dobře nerozlišoval mezi „transcendentní“ a „transcendentální“. V našem překladu jsme si dovolili jeho text upravit podle dnešních terminologických standardů.

49 „\$ VII. Concepto de la Evolución. - Restricciones. Importancia de los problemas ventilados. - Los seis días naturales y la fijeza de las especies: los días-épocas y la evolución orgánica. - Reseña histórica del evolucionismo: oposición y adhesiones. Osadías de Haeckel.“ EF1, s. 108-129.

50 „\$ VIII. La evolución en nuestros días. - Aceptación general: discrepancia de explicación. - Testimonios y apreciaciones: luz y concordia." Tamtéž, s. 130-142.

51 „\$ IX. Continuación. - Declaraciones famosas de Salisbury y de Brumetiére: decae el evolucionismo mecánico y va triunfando el teleológico. - Grandes probabilidades que éste tiene. - Corriente favorable entre los hombres de fe. - Evolucionistas principales." Tamtéž, s. 142-158.

52 „ X. Teorías espiritualistas. - Evolucionistas católicos.“ Tamtéž, s. 159-165.

53 „Entre esos escritores figura en primera línea el distinguido teólogo católico y eminente naturalista G. Mivart, quien probó magistralmente la impotencia de la selección mecánica é hizo ver cómo la evolución no puede realizarse sin un plan providencial y sin una tendencia innata en los organismos.“ - „Mezi těmito píśícími autory na prvním místě figuruje vynikající přírodovědec G. Mivart, který magistrálně prokázal nedostatečnost mechanicky pojímaného principu výběru a také to, že evoluce se nemůže odehrávat bez prozřetelnostního plánu a bez tendence, která je organismům vrozená." Tamtéž, s. 159. Arintero dále chválí, že Mivart odmítal evoluční vznik lidské duše, která může vzniknout jedině díky jedinečnému stvořitelskému zásahu Boha.

54 Srov. tamtéž, s. 160. 
Z. Gonzáles, který se zdráhá odsuzovat Mivarta, ale modifikuje jeho tezi v tom smyslu, že i lidské tělo vzniká sice z evolucí připraveného tvora, nicméně př́mým zásahem Stvořitele v okamžiku vdechnutí racionální duše. ${ }^{55}$ Upozorňuje se, že Nadaillac a Zahm berou Gonzálese velmi vážně, přesto jeho modifikaci ohledně dotvoření lidského těla v okamžiku vlití lidské duše nepovažují za logickou verzi a kloní se spíše k Mivartovi. ${ }^{56}$ Dále je uváděn M. D. Leroy, jehož Arintero chválín ${ }^{57}$ a zároveň se distancuje od jeho přemrštěností. Podle španělského dominikána francouzský bratr přeháněl $\mathrm{v}$ tom, že proměnlivosti druhů neklade žádné meze a že nedostatečně zdůrazňoval přímé Boží působení při vzniku lidského těla. Když se hovoří o Zahmově díle, Arintero se opět vyslovuje velmi pochvalně, vždyt' tohoto autora ve svém obecném úvodu velmi často cituje. Podivuje se a nerozumí tomu, proč bylo Zahmovo dílo dáno na seznam zapovězených spisů. ${ }^{58}$

Pro dnešního čtenáře je poněkud záhadné, jak je možné skloubit velmi pochvalné soudy děl Mivarta, Leroye a Zahma s tím, že na jiných stranách se k týmž spisům Arintero vyslovuje poměrně kriticky. Je evidentní, že na jedné straně s těmito autory souzní, nicméně si je velmi dobře vědom toho, že se jejich spisy setkaly s kritikou, ba odsouzením. Chce-li dosáhnout svého cíle, jímž je širší recepce umírněného evolucionismu, pak musí dát v určitém ohledu za pravdu i odpůrcům Mivarta, Leroye a Zahma. Celý problém tkví v jasnosti zdůrazňování priority Božího stvořitelského působení v evolučním procesu vzniku druhů na rovině fauny a flóry, zejména pak v otázce vzniku lidského těla. Nejenom v procesu vzniku druhů, ale především při vzniku lidského těla je Bůh podle Arintera vlastní účinnou př́ícinou jeho vzniku. Evoluční působení druhotných stvořených příčin je redukováno na rovinu materiální př́íčinnosti. ${ }^{59}$

Nejenom pro př́rodovědce bude tato interpretace transformistického vzniku druhů a lidského těla poněkud svízelná. Není totiž prokazatelná

\footnotetext{
Srov. tamtéž, s. 161.

Srov. tamtéž.

57 „Es ésta una obra seria, que contiene raciocinios solidísimos é irreplicables; $y$ ha contribuido poderosamente á desvanecer las prevenciones que muchas almas timoratas abrigaban en contra de la nueva doctrina.“ - „Je to seriózní dílo, které obsahuje velmi solidní a bezvadné myšlení. Výrazně přispělo k odstranění námitek, které mnozí bázliví obraceli proti této nové nauce." Tamtéž, s. 162.

58 Srov. tamtéž, s. 161-162.

59 Srov. tamtéž, s. 189. Arintero tímto způsobem interpretuje stanovisko Z. Gonzálese. Jenomže v jeho díle jsme žádné podobné tvrzení nenašli.
} 
na rovině experimentu, protože se jedná pouze o filosoficky laděnou interpretaci, která chce sladit údaje zjevení na jedné straně s př́rodovědeckou fakticitou. I dnešní teolog bude poněkud na rozpacích, protože Bůh stvořitel nejedná jako prostá stvořená účinná příčina, nýbrž spíše jako příčina stvořených příčin. Prostá příčina účinná je přece identifikovatelná přímo, a nejen na základě víry, případně filosofické rozvahy.

Vrat'me se ale k desátému paragrafu obecného úvodu k Arinterově osmisvazkové práci o evoluci. Určitě si povšimneme, že náš autor neví nic o případu italského autora R. Caverniho, který se jako první již v roce 1877 ve své publikaci veřejně připojil k Mivartovi a jeho nauce o evolučním vzniku lidského těla, a to na základě idejí vytěžených z myšlenkového odkazu A. Rosminiho.

Nyní dospíváme $k$ jedenáctému paragrafu, v němž Arintero souhrnně představuje své vlastní a originální filosofické přínosy, jejichž prostřednictvím by chtěl přesvědčit i odpůrce umírněného transformismu mezi katolickými mysliteli té doby. ${ }^{60}$

Arintero se v první řadě odvolává na dílo paleontologa a geologa Gaudryho ${ }^{61}$ podle něhož mezidruhová transformace existuje pouze v rámci zoologických a botanických tříd, nikoliv napříc těmito biologickými kategoriemi. ${ }^{62}$ Právě na tomto základě se pak vyjasňuje výše zmíněný princip rozlišování ontologického a biologického druhu. Zatímco onen ontologický se kryje s biologickou třídou, onen zoologický nebo botanický je dán akcidentálními odlišnostmi uvnitř třídy, a proto je proměnlivý. V rámci tříd může docházet k mezidruhové transformaci, ${ }^{63}$ protože druhy uvnitř tříd se neliší co do esence, nýbrž z filosofického hlediska pouze případkově. Stačilo by tudíž, aby Bůh na počátku stvořil ontologické druhy, prototypy živočišných a botanických tříd, a pak

60 „\$ XI. Nuestra Teoría.“ Tamtéž, s. 165-176.

${ }^{61}$ Sluší se připomenout, že se jedná o objevitele Dryopitheca.

62 „Tanto la Paleontología como la Zoología y Embriogenia vinieron á mostrarnos la exactitud de las afirmaciones de Gaudry, conviene á saber: que el encadenamiento, y por consiguiente, la evolución, existen sólo por regla general, en las clases.“ - „Jak paleontologie, tak zoologie a embryologie dokládají správnost Gaudryho tvrzení, tedy že příbuznost, a v důsledku toho také evoluce existují na základě obecného pravidla v třídách.“ Tamtéž, s. 168.

63 „... por ejemplo, los peces, las aves y los mamíferos difieren en la naturaleza esencial; por lo mismo no cabe transformación espontánea de una de estas clases á otra; pero dentro de cada una de ellas podrían en absoluto realizarce toda suerte de transformaciones...“ - „Kupř́ḱladu ryby, ptáci a savci se odlišují v přirozené esenci, a proto nedochází ke spontánní transformaci z jedné třídy do druhé, avšak uvnitř těchto tříd se v absolutním smyslu mohou uskutečňovat všechny podoby mezidruhové transformace..."Tamtéž, s. 170. 
se z těchto praživočichů mohly na základě evolučních mechanismů vyvíjet další druhy dané třídy - daného ontologického druhu. Ten je dán vitálním principem, druhem duše, který příslušnou třídu charakterizuje. Jasně zjištujeme, že Arintero byl vcelku pochopitelně vitalista, a odmítal mechanicistické pojímání transformismu a následně i života jako takového. Vlivy prostředí, pohlavního výběru, přirozeného výběru, to vše by byly jen druhotné př́íiny transformačního dění, protože ontologické druhy - třídy jsou od počátku dány a jsou neměnné díky stvořitelskému působení Boha, jenž je hlavní příčinou všech stvořených příčin. ${ }^{64}$ Tak by se zachovala nauka o nezměnitelnosti ontologického druhu a jeho přímém původu od Stvořitele s transformistickou či evolucionistickou naukou.

Bylo by ale omylem domnívat se, že jedna třída nemůže mít základ v jiné živočišné nebo botanické třídě. To však vždy vyžaduje speciální Boží zásah.

Jakmile určitý vitální princip poskytl všechny své možné projevy a jakmile přirozený řád volá po nových a odlišných druzích projevů, pak původní vitální princip nemůže dát vzniknout nějakému jinému vitálnímu principu, pokud nezasáhne Stvořitel, aby stvořil nový život a vtělil ho do zárodku, který bude esenciálně odlišný od předcházející formy života a který bude principem vývoje nové série organických druhů, které pak budou představovat nový metafyzický druh. Tento [nový ontologický] druh nevzniká spontánní transformací nebo evolucí z oněch předešlých, aniž by došlo k bezprostřednímu zásahu Stvořitele.

Ovšem Bůh při vytváření nového vitálního principu a při přípravě jemu odpovídajícího organismu neopomíjí druhotné příčiny v ničem, v čem by mohly k tomuto procesu přispět. Tyto přičiny sice nemohou zasahovat při vzniku nového vitálního principu, který je sám o sobě zcela jednoduchý, mohou však určitým způsobem připravit příslušný organismus. ${ }^{65}$

Srov. tamtéž, s. 174.

65 „Pero cuando un principio vital ha dado todas las manifestaciones posibles; cuando el orden natural clama por otra suerte de manifestaciones distintas, por la revelación de otra vida diversa, entonces ese principio vital no da origen á otro diferente, sino que interviene el Creador para crear ó producir de por sí una nueva vida, y encarnarla en un germen que resultará esencialmente distinto de los precedentes, y que dará principio á la evolución de una nueva serie de especies orgánicas, las cuales constituirán todas otra especie metafísica. Esta especie no se deriva, pues, por evolución 
To je, podle našeho mínění, klíčové místo arinterovského pojetí transformace druhů. Nový život, nová biologická tř́da nutně vyžaduje nový vitální princip, který je dán přímým Božím zásahem. Stvořitel však využívá druhotných, stvořených příčin, jejichž prostřednictvím připravuje adekvátní organismus, z jehož zárodku vzejde díky jím danému vitálnímu principu, duši, nový ontologický druh. $Z$ jevového hlediska vše probíhá jako evoluce, ve skutečnosti je tento vývojový skok přímo zapříčiněn stvořitelským zásahem Nejvyššího. Uvnitř třídy - ontologického druhu pak může docházet $\mathrm{k}$ bezpočtu variací a ke spontánní evoluci, což je jenom uskutečňování potencialit vložených na počátku do tohoto nového života. Tímto způsobem je zachováno něco z nauky antitransformistů, kteří mohou s klidným svědomím i vědomím přijímat tento omezený či limitovaný transformismus, aniž by to bylo v rozporu s tradiční naukou církve a především se zjevením.

Už nyní se zdá být velmi snadné uhodnout, jak se bude Arintero stavět k evolučnímu stvoření lidského těla. Jenomže na to musíme hledat odpověd' až ve dvanáctém paragrafu, kam náš autor zařadil přehledový plán celého svého osmisvazkového díla ${ }^{66}$ A právě v osmém dílu, který měl mít titul La Evolución y el Origen del Hombre, hodlal pojednat o původu člověka.

Člověk, když ho studujeme jako jeden celek, a nikoliv výhradně po organické stránce, je natolik odlišný od ostatních živočichů a převyšuje je, že to nezbytně vyžaduje, abychom ho zařadili nikoliv pouze do jiného druhu nebo tř́́dy, nýbrž dokonce do jiné říše. ${ }^{67}$

Jestliže ke vzniku nového ontologického druhu, tedy živočišné nebo rostlinné říše, je nutný zásah Stvořitele, který vlévá novému organismu nový vitální princip, pak v případě člověka, který není pouze novým

ó transformación espontánea de las precedentes, sino que recama una intervención inmediata del Creador.

Mas al producir Dios un nuevo principio vital y prepararle un organismo adecuado, no prescinde de las causas segundas en nada de lo que naturalmente puedan contribuir á esa obra; y esas causas, si no pueden intervenir en la producción de ese principio vital, por ser simplicísimo, pueden preparar de algún modo el organismo.“ Tamtéž, s. 174-175.

66 „\$ XII. Plan y resumen de esta obra.“ Tamtéž, s. 176-191.

67 „... el hombre, estudiado en su conjunto, y no únicamente en su organismo, es tan diferente de los demás animales y tan superior á ellos, quo requiere por necesidad ser colocado no ya en otro orden ni aun en otra clase, sino en un reino aparte." Tamtéž, s. 188. 
druhem, k čemuž by stačila normální evoluce uvnitř třídy, ani novou třídou (ontologickým druhem), ale prrímo novou říší života, bude nutný nanejvýš speciální přímý zásah Boží, přičemž ovšem stále platí, že k př́pravě organismu, z něhož bude pocházet lidské tělo, Stvořitel pochopitelně využije působení druhotných, stvořených přícin, tedy určitého druhu evoluce či transformace. Arintero hovoří přímo o:

... naprosto speciálním zásahu Stvořitele nejenom při stvoření nesmrtelné duše, ale dokonce také při formování nebo bezprostřední přípravě lidského těla. ${ }^{68}$

Tímto způsobem budou uspokojeni antitransformisté, zůstane v platnosti př́mé stvoření člověka Bohem, jak o tom vypovídají první kapitoly knihy Genesis. Jenomže na čistě jevové rovině se vše odehrává jako specifický evoluční skok. Když Arintero konstatuje, že v roce 1898 ještě scházejí paleoantropologické doklady přechodových forem vzniku člověka, měl v tom plnou pravdu, ${ }^{69}$ zejména když si uvědomíme, že neandrtálci byli mnohými hodnoceni jako skutečný lidský druh, což se shoduje s tím, co tvrdí paleoantropologové dnes. Duboisův objev pitekantropa (Pithecanthropus erectus) nebyl v oněch letech přijímán odbornou veřejností jako průkazný. Náš autor však velmi prozíravě konstatuje:

... ovšem rozum nás vede $k$ tomu, abychom věřili, že Bůh použil co nejvíce odpovídající materii nebo co nejlépe připravenou materii, tedy že nepoužil přímo bláto bez jakékoliv př́pravy, ale spíše speciální půdu, půdu připravenou a organizovanou. ${ }^{70}$

Potvrzením toho, že Juan Gonzáles de Arintero se přikláněl k evolučnímu vzniku - stvoření lidského těla je fakt, že se v dané věci hlásí k té nauce, kterou v roce 1891 předložil kardinál Zeferino Gonzáles. ${ }^{71}$

68 „... una intervención especialísima del Creador, no sólo para la creación del alma inmortal, sino también para la formación ó preparación inmediata del mismo cuerpo.“ Tamtéž, s. 188.

69 Srov. tamtéž, s. 189.

${ }^{70}$ „... y la razón nos induce á creer que Dios tomó la materia más adecuada ó mejor preparada: que no tomó directamente el lodo sin ninguna preparación, sino un lodo ó limo especial, preparado, organizado.“ Tamtéž, s. 189.

71 „Nos parece, pues, muy razonable la hipótesis del P. Zeferino, la cual, aparte de ser de una ortodoxia intachable, deja plenamente á salvo nuestros sentimientos acerca 
Vyvstává otázka, zda Juan Gonzáles de Arintero byl zastáncem evolučního vzniku člověka, či nikoliv. ${ }^{72}$ Podle našeho soudu určitě ano, protože na jevové rovině uznával evoluci v oblasti fauny a flóry a následně rovněž evoluční vznik lidského těla. Na interpretační rovině dokázal jednak velmi výrazně podtrhnout stvořitelské působení Boha, jednak recepci evoluce na rovině faktů a jevů vyložil tak, že byla plně v souladu s tradiční křestanskou a zřejmě i judaistickou naukou o stvoření člověka Nejvyšším.

\subsection{Problematika evolučního vzniku - stvoření človéka $v$ ostatních dílech Juana Gonzálese de Arintero}

Zahledíme-li se do rukopisu needitovaného osmého svazku díla $L a$ Evolución y la Filosofía Christiana 8. La Evolución y el Origen del Hombre (EFC 8), nacházíme v něm potvrzení toho, co jsme objevili v námi podrobně zkoumaném obecném úvodu k celému dílu:

Nuže tedy, jestliže živočichové mohou určitým způsobem připravit elementy, nemohou ho [lidské tělo] připravit zcela a úplnè, nemohou ho disponovat pro rozumovou duši, nemohou poskytnout takovou př́pravu, kterou rozumová duše vyžaduje. $\mathrm{Z}$ uvedeného důvodu naše tělo $\mathrm{v}$ tom, co má opravdu lidského, a nakolik je esenciální součástí našeho bytí a určitým způsobem také nástrojem inteligence, nemůže pocházet z evoluce ... vším, čím je, je př́ímým dílem Božím. (...) Tohle nám říká pravdivé odůvodnění a priori a tamto je to, co aposteriorně potvrzují všechny údaje přírodních věd. ${ }^{73}$

de la nobleza de nuestro origen. Siendo el mismo Dios quien formó el organismo del primer hombre, no cabe mayor dignidad; pues la materia de que lo formó no compromete en nada la nobleza de la formación ... se compromete en nada por la procedencia animal de los alimentos á expensa de los cuales se rehace ó regenera.“ - „Zdá se nám, že hypotéza otce Zeferina je nejracionálnější, nebot' je z hlediska pravověří nenapadnutelná a zároveň plně uspokojuje naše cítění ohledně vznešenosti našeho organismu. Je-li sám Bůh, kdo formoval organismus prvního člověka, pak neexistuje větší důstojnost. Materie nemůže nikterak kompromitovat tuto vznešenost ... stejně ji nikterak nekompromituje animální původ potravy, jíž se člověk živí a obnovuje.“ Tamtéž, s. 190.

72 Srov. Francisco Pelayo. Darwinism and Paleontology: Reception and Diffusion of the Theory of Evolution in Spain. In: Eve-Marie Engels - Thomas F. Glick. The Reception of Charles Darwin in Europe 1-2. London: Continuum; New York: 80 Maiden Lane 2008, s. 386-399, zde 394. Autor př́spěvku ve velmi prestižní publikaci výslovně tvrdí, že Arintero odmítal evoluční vznik člověka, což - jak vyplývá z naší lektury - není adekvátní hodnocení jeho postoje.

75 „Así pues, si los animales puderion preparar de alguna manera los elementos, no poderían preparar de nignuna manera, darle la última mano, non poderían disponer- 
Zároveň ale živočišné organismy připravily substrát, z něhož Bůh bezprostředním zásahem stvořil lidské tělo, které je vhodné pro sjednocení s rozumovou duší.

[Tyto živočišné organismy] určitým způsobem připravily náš příchod a předaly nám dispozice a ty elementy svého organismu, které pak na základě posledního zásahu samotného Boha a spolu s vlitím racionální duše vedly ke vzniku výlučně lidského těla. ${ }^{74}$

Náš autor tedy v osmém svazku svého zamýšleného díla v ničem nezměnil svou pozici. Je zastáncem evolučního vzniku člověka z živočišných předků, ale zároveň zachovává nauku o stvoření člověka Bohem, přičemž na rozdíl od Mivarta spolu se Zeferinem Gonzálesem obhajuje mnohem důsledněji důstojnost nejenom lidské duše, ale také lidského těla.

Nemělo by nás překvapovat, že v již zmíněném Arinterově díle $E l$ Hexámeron y la Cinecia moderna (HXCM) se setkáváme s totožným popisem evolučního vzniku - stvoření člověka jako v díle o tři roky mladším.

Ćlovék je na jedné straně zcela odlišný od ostatních živočichů, na druhé straně je však také jejich potomek. ${ }^{75}$ Určitě by nám neměla uniknout jedna velice zajímavá skutečnost, totiž že Juan Gonzáles de Arintero bral velmi vážně paralelismus mezi embryonální ontogenezí a evoluční cestou druhu, tedy fylogenezí:

... je více méně jasné, že v průběhu individuálního vývinu [člověka] se projevují fáze, kterými prošel lidský druh, nemůže tedy být ani jinak, že do popředí vystupují velmi zřetelně obdoby se zděděnými charakteristikami opa... ${ }^{76}$

lo para el alma racional, non poderían darle otra disposición distinta de la que require el de ellos. Por lo tanto nuestro cuerpo, en lo que tiene de humano, en cuanto que es parte esencial de nuestro ser y de alguna manera órgano de la inteligencia, non pudo provenir de la evolución..., y tuvo que ser obra directa del mismo Dios. ... Esto es lo que nos dice la recta razón a priori y esto es lo que confirman a posteriori todos datos de las cencias naturales.“ - Gonzáles Arintero. La evolución y la filosofía cristiana 8. La evolución y el origen del hobre. Fondo Juan Gonzáles Arintero O.P. del convento de San Esteban, č. DO 7.2. 3, s. 70. (EFC8).

74 „Han preparado de algún modo nuestra venida, y nos han trasmitido muy convenientemente dispuestos y preparados ya los elementos de su organismo, que con una última disposición hecha po el mismo Dios y con la infusión del alma racional, resultó exclusivamente humano.“ EFC8, s. 84. Srov. HXCM, s. 84.

76 „El hombre ... debe reconocerse de una manera más o meno clara, durante su desarollo individual, las fases por las que atravesó la especie, non puede menos de apa- 


\section{Závèr}

Jak jsme již konstatovali, Juan Gonzáles de Arintero plnoprávně patří mezi průkopníky křestanské recepce evoluce v oblasti fauny a flóry a evolučního vzniku lidského těla. Tvrzení, že odmítal evoluční vznik lidského těla, je podle nás hrubě nespravedlivé, protože člověk je podle něj biologicky potomkem vyšších primátů a ontogeneze vykazuje paralely s fylogenezí. Na interpretační, tedy filosoficko-teologické, a proto světonázorové rovině však danou skutečnost nedokáže pochopit bez přímého zásahu Boha stvořitele. Toto přesvědčení se čistě př́rodovědecky nedá ani potvrdit, ani vyvrátit, což ovšem platí v naprosto stejné míře pro opačné světonázorové přesvědčení, podle něhož by vznik člověka měl být jen důsledkem samotného mechanicisticky pojímaného evolučního pohybu, a to na základě čiré nahodilosti, bez jakéhokoliv cíleného směřování daného procesu. Nezbývá nám než věřit bud' v Boha stvořitele, anebo „věřit“ v jeho nejsoucnost a čirou nahodilost. Odůvodňování právě zmíněných postojů se odehrává na filosofické, případně teologické rovině, kde hledáme důvody pro racionalitu naší víry či „víry“.

Svým rozlišením ontologického druhu (zoologická a botanická třída) a zoologického či botanického druhu Arintero nastolil interpretačně dvě roviny. Na jevové rovině existuje spontánní evoluční pohyb v rámci třídy - ontologického druhu. Velmi výjimečně dochází ke zrodu nové třídy, nového ontologického druhu, což ale vyžaduje zcela př́mý zásah Boha, jenž připravuje nový organismus z původního a vybavuje ho novým vitálním principem, duší. Tímto zpo̊sobem se Arinterovi daří propojovat empirické údaje přírodních věd s klasickou naukou o stvoření druhů Bohem.

Arintero tak vlastně doplnil teorii Zeferina Gonzálese o evolučním vzniku - stvoření člověka, což vyžaduje naprosto speciální zásah Boží nejenom co do vzniku lidské duše, ale také lidského těla. Lidské tělo ale Bůh tvoří z organické látky, konkrétně z opů, k čemuž důsledně využíval druhotných stvořených příčin. Od Mivarta se Arintero stejně jako Z. Gonzáles liší tím, že mnohem zřetelněji zdůrazňuje Boží působení v procesu evoluce, což ovšem právě zmínění autoři rozhodně nemínili popírat. Oba španělští dominikáni také výrazněji než předchozí autoři

recemos mucho mejor marcado con los caracteres hereditarios del mono." HXCM, s. $98-99$. 
podtrhovali nesmírnou důstojnost nejen lidské duše, ale také lidského těla.

Katolická teologická fakulta Univerzity Karlovy Katedra fundamentální a dogmatické teologie Thákurova 3 16000 Praha 6 - Dejvice E-mail: pospisil@ktf.cuni.cz 